\title{
PRZEGLAD WYBRANYCH METOD PRACY Z DZIEĆMI Z AUTYZMEM W WIEKU WCZESNOSZKOLNYM
}

\begin{abstract}
Streszczenie
W artykule podjęta została tematyka sposobów pracy z dziećmi z autyzmem w wieku wczesnoszkolnym. Opisane zostały cechy charakterystyczne dla tego zaburzenia jakim jest autyzm. Przedstawione zostały metody zaliczające się do dyrektywnych oraz niedyrektywnych form pracy. Autorka opisała w skrótowy sposób najważniejsze cechy poszczególnych terapii. W konkluzji zawarła twierdzenie, iż w doborze metod pracy z dziećmi z autyzmem konieczne jest uwzględnienie przede wszystkim potrzeb dziecka, jego możliwości oraz barier. Ponadto, podniesiona została ważność systematycznej i intensywnej pracy terapeutycznej oraz współpraca specjalistów oraz rodziców.
\end{abstract}

Słowa kluczowe: autyzm, metody pracy, edukacja wczesnoszkolna

\section{Wprowadzenie}

Współcześnie odnaleźć można wiele proponowanych w literaturze i praktykowanych metod pracy z dziećmi z autyzmem w wieku wczesnoszkolnym. Mają one rozmaite formy, różnorodne postępowanie i kierunki oddziaływania, jednak wspólnym ich celem jest poprawianie ogólnego stanu dziecka oraz terapia zaburzonych sfer. Będąc specjalistą pracującym z osobami z autyzmem warto poznawać różne, nowe metody terapii, co z pewnością będzie owocowało i dawało pozytywne rezultaty interwencji terapeutycznych. 


\section{Charakterystyka osób z zaburzeniami ze spektrum autyzmu}

$\mathrm{Na}$ wstępie rozważań dotyczących zaburzenia oraz funkcjonowania osób z autyzmem należy podjąć się próby definicji samego pojęcia. Termin autyzm (autismus), został wprowadzony do psychiatrii w 1911 roku przez Eugeniusza Bleulera i na początku oznaczał „odwrócenie się”, a co za tym idzie, wyizolowanie od świata zewnętrznego oraz widoczną przewagę życia wewnętrznego nad zewnętrznym (Falzeder 2007: 37, za: Gerc 2012). Autyzm niegdyś klasyfikowany był jako jeden z najważniejszych aspektów widocznych w schizofrenii i postrzegano go jako skutek lub składową rozszczepienia schizofrenicznego.

Nawiązując do historycznego rysu zaburzenia jakim jest autyzm, należy powrócić do lat czterdziestych dwudziestego wieku, kiedy to tacy badacze jak Leo Kanner oraz Hans Asperger, niemal w tym samym czasie, choć niezależnie od siebie, opisali wykryte jednostki kliniczne, nazwane w tamtym okresie: autyzmem wczesnodziecięcięcym oraz psychopatią autystyczną, określaną współcześnie jako zespół Aspergera (Gerc 2012). Wspomniani naukowcy opisali zaobserwowane u swoich pacjentów trudności w obrębie relacji społecznych oraz komunikacji, posługując się właśnie określeniem „autyzm”.

Współcześnie, dokonując analizy i opisu funkcjonowania oraz terapii osób z autyzmem przede wszystkim należy zwrócić uwagę, na rzecz oczywistą, choć czasem zapominaną. Podobnie jak nie można wskazać dwóch takich samych osób w społeczeństwie, tak samo nie odnajdziemy dwóch takich samych osób z autyzmem, które będą funkcjonowały w identyczny sposób. Takie założenie powinno stanowić punkt wyjścia do doboru metod pracy oraz projektowania każdego indywidualnego programu terapeutycznego dedykowanego osobie z autyzmem.

Odnosząc się do charakterystycznych dla autyzmu cech warto wskazać, iż w literaturze odszukać można różne opisy zachowań osób z zaburzeniami ze spektrum autyzmu (Cieszyńska 2011). Wiedza dotycząca funkcjonowania osób z autyzmem jest coraz szersza, a dzięki coraz większym możliwościom diagnostycznym możliwe jest szybsze rozpoznanie tej jednostki u dzieci. Jednocześnie pozwala to lekarzom, terapeutom i rodzicom na szybkie podjęcie odpowiednio dobranych, zindywidualizowanych działań leczniczo-terapeutycznych (Komorowska-Szczepańska 2015).

W pewnej pozycji (Mesibov, Shea 2009: 3 za: Wolski 2012), odnaleźć można takie wyjaśnienie specyfiki tego zaburzenia: Autyzm (...) to upośledzenie rozwoju wywotane zaburzeniami neurologicznymi. Wptywa na sposób, w jaki poszczególne osoby jedza, ubieraja się, pracuja, spędzają swój wolny czas, rozumieja świat, komunikuja się, itp. W ten sposób autyzm może być rozumiany jako kultura, ponieważ sktada się z charakterystycznych i przewidywalnych wzorców zachowań. (Mesibov, Shea 2009: 3 za: Wolski 2012). Powyższy opis, wydaje się zwracać uwagę na szczególną oraz 
znaczną odmienność osób z autyzmem od neurotypowych przedstawicieli społeczeństwa. Jednak odszukać można w przytoczonym fragmencie pozytywny wydźwięk nadany opisowi, gdyż autyzm jest tu przedstawiony jako kultura czyli cecha danego człowieka.

Jak zostało już wcześniej wspomniane autyzm jest zaburzeniem neurorozwojowym, a obserwowane objawy występują w trzech sferach funkcjonowania dziecka: interakcji społecznych, komunikacji oraz w zachowaniach, przejawiających się na przykład pod postacią powtarzalności - stereotypii (Komorowska- Szczepańska 2015).

W pierwszej z wyżej wymienionych kategorii czyli interakcji społecznych, należy wspomnieć, że dzieci z autyzmem mają trudności z odczytywaniem emocji, rozumieniem przyczyn emocji, myśli, intencji różnych osób i zamiarów innych ludzi. Jest to powiązane z zaburzoną zdolnością do intuicyjnego myślenia o swoich i cudzych myślach, nazywane jest to Teorią Umysłu (http://www.synapsis.org.pl/ zycie-z-autyzmem/poradnik-dla nauczycieli/funkcjonowanie-osob-z-autyzmemna-co-zwroci-szczegoln-uwag). W podanym poniżej opisie dopatrzeć można się właśnie tych cech: Nie patrzq w oczy... nie reaguja na to, co mówimy... sq czymśs zajęte, wręcz pochtonięte (...). Mówimy, że sq wtedy "wytączone”, poza interakcją, skupione na sobie i swoich odczuciach" (Kaufman 2016: 9). Wskazane cechy wydaja się być najczęściej podnoszone w opisach osób z autyzmem. Wyróżnia się tu fakt, iż te osoby skupiają swoją uwagę raczej na przedmiotach, a niżeli ludziach. Ponadto, dziecko z autyzmem ma zaburzoną zdolność do naprzemiennego, dwustronnego uczestniczenia w interakcjach społecznych. Jest to szczególnie widoczne w przypadku dzieci w wieku przedszkolnym lub wczesnoszkolnym, kiedy to neurotypowe dzieci nawiązują nowe interakcje, uczą się nowych zasad, uczestniczą we wspólnej zabawie i rozwijają swoje umiejętności interpersonalne, natomiast dzieci z autyzmem mają z tym znaczne trudności.

Kolejna wymieniona sfera, w której pojawiają się trudności u dzieci z autyzmem to mowa i komunikacja. Deficyty językowe u dzieci z autyzmem można zaobserwować już w pierwszych miesiącach życia. Są nimi brak u małego dziecka gaworzenia oraz zanik rozwijających się umiejętności językowych (Skawina 2016). W późniejszym okresie życia dziecka najbardziej widoczne są trudności w inicjowaniu, kontynuowaniu oraz podtrzymywaniu rozmowy, zarówno z dorosłymi, jak w relacji z rówieśnikami. Widoczne są tu trudności z budowaniem złożonych wypowiedzi, odwracanie zaimków, popełnianie błędów gramatycznych oraz nieumiejętność prowadzenia naprzemiennej rozmowy. Do charakterystycznych trudności w zakresie komunikacji można dodać także częste echolalie oraz zaburzoną prozodię mowy (Skawina 2016).

Trzecim kryterium jakie wyróżnia autyzm z pośród innych zaburzeń jest występowanie ograniczonych, sztywnych stereotypowych wzorców aktywności, za- 
chowania oraz zainteresowań, a także możliwe kompulsywne przywiązanie. Owe zachowania mogą powodować oraz nasilać u osób z zaburzeniami ze spektrum autyzmu trudności w podejmowaniu interakcji społecznych i zaburzać komunikację.

Biorąc pod uwagę powyższe, rozwijanie umiejętności społecznych oraz komunikacji oraz praca nad prawidłowymi wzorcami zachowania u dzieci z autyzmem wydają się być kluczowymi celami w terapii. Dzieci te powinny mieć zapewnione zajęcia specjalistyczne ukierunkowane na poprawę funkcjonowania w środowisku, oparte na metodach dedykowanych właśnie tej grupie osób. W doborze metod pracy należy kierować się właśnie tym, które formy terapii będą pomocne przy niwelowaniu trudności charakterystycznych dla osób z autyzmem, jednocześnie będą odpowiednie dla danej grupy wiekowej.

\section{Wybrane metody pracy z uczniem z autyzmem w wieku wczesnoszkolnym}

Podejmując się opracowania wybranych metod pracy z uczniem z autyzmem można podawać i przytaczać przykłady licznych form oddziaływania. Warto jednak podkreślać, jak niezwykle ważne i pomocne może być stosowanie odpowiedniej terapii celem pozytywnego oddziaływania, w tym wzmocnienia uwagi, poprawy relacji społecznych, zmniejszenia stereotypii oraz zmniejszenia nasilenia zachowań destrukcyjnych.

Bardzo ważnym aspektem, który powinien niejako stać się mottem specjalistów podejmujących terapię czy wspomaganie osób z zaburzeniami ze spektrum autyzmu jest to, że to nie dziecko powinno być dopasowywane do metody, a właśnie metoda dobrana i wprowadzana na potrzeby dziecka. Ponadto, terapia powinna być konkretnym, przemyślanym oraz zaplanowanym, wieloaspektowym procesem, który obejmuje różne sfery systemowego i świadomego działania zarówno terapeuty jak i rodziców dziecka (Skawina 2016). Powinna ona uwzględniać złożoność zaburzeń, a także potrzeby osoby i jej środowiska. W chwili obecnej pomimo wielu lat badań i poszukiwań nie udało się odnaleźć wyłącznie jednej skutecznej metody terapii (Szeler 2007). Liczne sposoby oddziaływania mogą dawać pozytywne rezultaty, pod warunkiem, że są odpowiednio dopasowane do dziecka, uwzględniają jego możliwości oraz wychodzą naprzeciw potrzebom. Co ważne, niezależnie od wybranej metody czy formy oddziaływania terapeutycznego istotną rolę odgrywają przede wszystkim systematyczność oraz intensywność ćwiczenia.

Wykorzystywane w pracy z dzieckiem z zaburzeniami ze spektrum autyzmu podejścia mogą się uzupełniać, przeplatać, być wykorzystywane w różny sposób, na rozmaitych etapach życia dziecka. Co najważniejsze, rozpoczęcie wspomagania oraz 
terapii we wczesnym okresie życia dziecka jest dobrą bazą do dalszego rozwijania umiejętności i zdolności społecznych i emocjonalnych. Zatem można stwierdzić, że im wcześniej uda się rozpocząć pracę nad zaburzonymi funkcjami, tym więcej uda się osiągnąć, a tym samym dziecko w przyszłości będzie mogło zacząć opanowywać złożone umiejętności (Szeler 2007). Powyższe twierdzenie bazuje na założeniu, iż we wczesnym okresie rozwoju układ nerwowy dziecka charakteryzuje się wyjątkowo dużą plastycznością, dzięki której możliwa jest skuteczna korekcja zaburzonych funkcji oraz kompensacji deficytów (Szeler 2007).

W kategorii terapii dzieci z zaburzeniami ze spektrum autyzmu można wyróżnić ich dwa typy czy też rodzaje, które wyróżniają się formą ingerencji i rolą terapeuty. Podaje się metody dyrektywne i niedyrektywne.

Uogólniając można uznać, że niedyrektywność oznacza u terapeuty powstrzymywanie się od wydawania poleceń oraz ingerowania w sytuacji terapeutycznej i podczas zabawy dziecka (Szeler 2007). Celem niedyrektywnej formy terapii jest przede wszystkim obniżanie napięcia oraz lęku, a także uczenie się zachowań akceptowanych i aprobowanych w środowisku przez osoby z zaburzeniami ze spektrum autyzmu.

Do wspomnianej powyżej niedyrektywnej grupy metod pracy z osobami z zaburzeniami ze spektrum autyzmu należy Program Son-Rise. Bazuje on na przekonaniu, że dziecko z autyzmem odbiera świat jako niezrozumiały, zagrażający i w efekcie wycofuje się, zamyka przed nim. Dzieje się tak szczególnie w przypadku dzieci młodszych, które dopiero poznają i odkrywają świat, który tym bardziej wydaje im się obcy. Program Son-Rise został opracowany przez rodziców dziecka z zaburzeniami ze spektrum autyzmu dla rodziców oraz profesjonalistów. Według założeń programu Son-Rise rodzice są dla dziecka najlepszym źródłem informacji. W czasie szkolenia, rodzice uczeni są konkretnych metod oraz narzędzi dotyczących edukacji i postaw oraz technik oddziaływania oraz pracy z dzieckiem z autyzmem. Najważniejszymi aspektami metody Son-Rise jest konieczność dołączania przez terapeutę do rytualistycznych i powtarzających się zachowań dziecka, które ułatwia nawiązanie kontaktu, rozwój socjalny, kontakt wzrokowy i włączenie się do zabawy $\mathrm{z}$ innymi (http://niegrzecznedzieci.org.pl/asperger/swiat-nauki/terapia/metoda-opcji/). Ponadto, twórcy metody zakładają, że nauka poprzez zabawę w formie interaktywnej, powoduje efektywną socjalizację oraz daje postępy w budowaniu i nauce interakcji dzieci z zaburzeniami ze spektrum autyzmu. Terapia metodą Son-Rise jest prowadzona najczęściej w domu dziecka przez rodziców lub specjalistów i wolontariuszy w specjalnie przygotowanym i zaadaptowanym do tego celu pomieszczeniu (Skawina 2016). Taki układ sprzyja zapewnieniu poczucia bezpieczeństwa i rozwoju dziecka z autyzmem w przyjaznych, znanych mu warunkach.

Kolejną metodą z grupy terapii niedyrektywnych jest Program Aktywności Marianny i Christophera Knillów. Została opracowana przez małżeństwo Ma- 
riannę i Christophera Knillów i polega na wykonywaniu specjalnie dobranych i przygotowanych zestawów ćwiczeń z akompaniamentem muzyki. Metoda ta bazuje na wrażliwości zmysłu dotyku, a doświadczenie kontaktu fizycznego staje się bazą do rozwoju kontaktów z innymi osobami. (Puszczałowska-Lizis, Biała 2017). Zgodnie z opisem pomaga dzieciom z zaburzeniami ze spektrum autyzmu w zdobywaniu świadomości swojego ciała, w odczuwaniu jego części, nauce ruchów celowych i kontrolowanych oraz w nauce naśladownictwa. Z założeń wynika, iż ma ona wpływ na rozwijanie i poprawę kontaktu wzrokowego oraz uczy współpracy z drugim człowiekiem. Są to niezwykle cenne aspekty do rozwijania zwłaszcza u dzieci w wieku wczesnoszkolnym. W tym wypadku zastosowanie w tej metodzie muzyki, ram czasowych i stałych aktywności daje dzieciom poczucie przewidywalności i bezpieczeństwa. Zajęcia prowadzone metodą Knillów powinny być prowadzone w odpowiednim pomieszczeniu, zapewniony powinien być spokój oraz relaks uczestnika terapii. Mogą one być stworzone poprzez oświetlenie, wygodną pozycję na materacu oraz uwzględnienie indywidualnych potrzeb wynikających z pory dnia (Puszczałowska-Lizis, Biała 2017). Ma to duże znaczenie i daje dużą korzyść zwłaszcza w przypadku dzieci z autyzmem, ze względu na dużą potrzebę rytualizacji oraz dopasowanie warunków do możliwości i wrażliwości tych dzieci.

Kolejną metodą pracy, zaliczaną do form niedyrektywnych jest Metoda Integracji Sensorycznej ( $\mathrm{z}$ ang. SI, Sensory Integration). Powstała ona w Stanach Zjednoczonych Ameryki, a jej autorką jest Jean Ayres. Stworzona została w oparciu o wiedzę oraz doświadczenie płynące z takich dziedzin jak: psychologia, neurofizjologia oraz anatomia (Odowska-Szlachcic 2013). Sama integracja sensoryczna jest procesem organizującym wrażenia płynące z ciała, zmysłów oraz środowiska w taki sposób, by mogły zostać one prawidłowo i optymalnie wykorzystane. Bardzo ważna jest integracja systemów zmysłowych, w tym: wzrokowego, słuchowego, dotykowego, przedsionkowego, proprioceptywnego oraz układu smaku i węchu (Odowska-Szlachcic 2013). Autorka metody, wskazywała, że odpowiednia integracja sensoryczna jest podstawą do prawidłowego rozwoju ruchowego, uczenia się oraz zachowania (Puszczałowska-Lizis, Biała 2017). W myśl za tym, można uznać, że prawidłowe funkcjonowanie dziecka, w tym także tego w wieku wczesnoszkolnym jest zależne od ogólnego rozwoju psychoruchowego. W przypadku dzieci $\mathrm{z}$ autyzmem mogą występować liczne zaburzenia integracji sensorycznej. Dzieci te mogą charakteryzować się nadwrażliwością na różne bodźce lub być podwrażliwe i nie reagować na określone sensoryzmy. Jak twierdzi Grandin (2018), naukowcy badający osoby z zaburzeniami ze spektrum autyzmu analizując ich trudności, skupili się na rozpoznawaniu twarzy i komunikacji społecznej, zaniedbując przy tym niezwykle ważną sferę jaką jest integracja zmysłowa. Co więcej, zaburzenia procesów integracji sensorycznej mogą powodować trudności w innych sferach takich 
jak komunikacja, rozwój motoryczny, społeczny czy emocjonalny. Nadwrażliwość sensoryczna dla niektórych osób z autyzmem zdarza się być całkowicie wyniszczająca (Grandin 2018). Warto to odnieść do potrzeb dzieci w wieku wczesnoszkolnym, dla których zaspokojenie potrzeb płynących z ciała pozwala na rozpoczęcie oraz dokonywanie efektywnego procesu nauczania i terapii. Zastosowanie metody Integracji Sensorycznej w przypadku dzieci z autyzmem będzie dawało okazję do nauki rejestracji oraz modulowania doznań zmysłowych, które mają wpływ na poziom pobudzenia oraz odczuwane emocje, w konsekwencji edukację (Puszczałowska-Lizis, Biała 2017).

Jako kolejną w obrębie niedyrektywnych metod pracy z dziećmi z trudnościami rozwojowymi wyróżnić można Metodę Ruchu Rozwijającego Weroniki Sherborne. Metoda ta, stworzona w latach 60. XX wieku, znajduje zastosowanie w pracy z dziećmi z różnymi dysfunkcjami, w tym z zaburzeniami ze spektrum autyzmu, z niepełnosprawnością intelektualną, porażeniem mózgowym, zespołem Downa, zaburzeniami emocjonalnymi i behawioralnymi (Biernat 2014). Do podstawowych założeń metody można zaliczyć rozwijanie się za pomocą ruchu: świadomości ciała, przestrzeni oraz funkcjonowania w niej, a także dzielenia przestrzeni z innymi osobami, a co za tym idzie nawiązywanie z nimi pozytywnych relacji (Sherborne, 1999, za; Puszczałowska-Lizis, Biała 2017). Ruch w tej formie oddziaływania jest źródłem doznań kinestetycznych oraz okazją do kontaktu fizycznego i podejmowania różnych kontaktów w przyjaznej atmosferze. Dzieci z zaburzeniami ze spektrum autyzmu w czasie zajęć Ruchu Rozwijającego Weroniki Sherborne mogą testować i trenować swoje umiejętności społeczne, budować poczucie własnej tożsamości oraz nawiązywać nowe relacje co jest bardzo ważne, zwłaszcza w przypadku dzieci będących na etapie edukacji wczesnoszkolnej.

Obok wymienionych powyżej metod jako niedyrektywne formy pracy z dziećmi z autyzmem można wskazać wszelkiego rodzaju animaloterapie oraz arteterapie. Pośród wskazanych animaloterapii można wymienić szczególnie korzystne dla dzieci z autyzmem: dogoterapię (terapię z udziałem psa), felinotreapię (terapię z udziałem kota), hipoterapię (terapię z udziałem konia) czy ostatnio coraz bardziej rozpowszechnioną alpakoterapię. Terapie z udziałem zwierząt mają wielofunkcyjne oddziaływanie na różne sfery funkcjonowania dziecka. Zazwyczaj dają one efekt skumulowany, łączący w sobie np. funkcję fizyczną (usprawnianie) z psychiczną, edukacyjną lub motywacyjną, a często wszystkie naraz (Chmiel, Kubińska, Derewiecki 2014).

Do arteterapii zaś zaliczyć można takie terapie jak: plastykoterapię, teatroterapię, biblioterapię, czy muzykoterapię, Pozwalają one osobie z autyzmem na nawiązanie kontaktuz innymi, uwzględnienie jej potrzeb, możliwości oraz barier. Powyższe metody są niezwykle korzystne, zwłaszcza dla dzieci będących w wieku wcze- 
snoszkolnym. Powyższe metody pracy są o tyle polecane dla dzieci z autyzmem, ponieważ w czasie ich prowadzenia możliwe jest zachowanie dowolności oraz podążanie za dzieckiem jednocześnie wzbudzając zainteresowanie oraz oddziałując na zaburzone sfery.

W opozycyjnych do powyższych form prowadzenia terapii, a więc w metodach dyrektywnych sposób prowadzenia terapii bazuje przede wszystkim na behawioralnym przekonaniu, że w dowolny sposób można kształtować zachowanie poprzez odpowiednie manipulowanie (Szeler 2007).

Przykładem dyrektywnej formy terapii jest Program TEACCH (Treatment and Education of Autistic and Related Communication Handicapped Children), czyli program Terapii i Edukacji Dzieci Autystycznych oraz Dzieci z Zaburzeniami w Komunikacji. Metoda ta została stworzona przez dr Erica Schoplera i dr Roberta Reichera w 1966 roku. Według założeń tej metody, podstawą do zrozumienia funkcjonowania osób z zaburzeniami ze spektrum autyzmu są określone wyznaczniki. Metoda TEACCH zakłada, że najlepszymi umiejętnościami pojawiającymi się u osób z autyzmem są dobra pamięć, percepcja, a także zdolności wysepkowe (https://polskiautyzm.pl/podejscie-teacch-w-terapii-autyzmu/). Głównym celem oddziaływania zgodnie z Programem jest rozwijanie zdolności i umiejętności adaptacyjnych, a co za tym idzie przystosowawczych do środowiska społecznego. Nadrzędnym zaś celem jest rozwijanie niezależności i samodzielności dziecka, na każdym etapie rozwoju. W metodzie tej wykorzystywane są przede wszystkim założenia teorii poznawczych oraz behawioralnych celem wyjaśniania i stwarzania bezpiecznego otoczenia dla osób z zaburzeniami ze spektrum autyzmu (Pisula 2010). Działania mogą być realizowane poprzez strukturalizowanie środowiska poprzez indywidualizowanie oraz przygotowanie odpowiedniego planu pracy, organizowanie otoczenia i wydawanie prostych komunikatów, a także wskazywanie jasno na oczekiwania. Ważnym elementem metody TEACCH jest oddziaływanie na trudności ale jednocześnie uwzględnienie oraz akceptowanie specyfiki problemów wynikających z autyzmu (Pisula 2010).

Inną formą terapii zaliczaną do dyrektywnych metod jest sama terapia behawioralna. Stosowanie teorii behawioralnej w terapii dzieci z zaburzeniami ze spektrum autyzmu zapoczątkował C.B. Ferster w latach sześćdziesiątych. Najważniejszym elementem podejścia behawioralnego jest koncentracja na zachowaniu (Kozłowski 2003, za: Pisula 2010). Zdaniem Kołakowskiego i Pisuli (2016), celem terapii behawioralnej jest zmienianie niepożądanych objawów czy trudnych zachowań. Stosowanie terapii behawioralnej w przypadku osób z zaburzeniami ze spektrum autyzmu w wieku wczesnoszkolnym pomaga zaspokoić potrzebę rytualizacji oraz konsekwencji, a także powtarzalności zachowania i czynności. Do głównych celów terapii behawioralnej można zaliczyć rozwijanie zachowań deficytowych, na 
przykład zabawy tematycznej czy prawidłowej mowy, które są pożądane i prawidłowe. Innym celem jest redukcja zachowań niepożądanych, które zakłócają naukę oraz generalizowanie i utrzymywanie efektów terapii poprzez kontrolowanie okoliczności w jakich różne zachowania się ukazują (Puszczałowska-Lizis, Biała 2017). W terapii behawioralnej stosowane są techniki rozwijające pozytywne zachowania oraz nowe umiejętności. Przede wszystkim wykorzystuje się różne wzmocnienia mające na celu powielanie przez dziecko pożądanych czynności oraz procedury mające na celu wygaszanie nieoczekiwanych reakcji (Pisula 2010).

Kolejną metodą zaliczaną do dyrektywnych form oddziaływania wykorzystywaną w terapii dzieci z zaburzeniami ze spektrum autyzmu jest Metoda Stymulowanych Seryjnych Powtórzeń Ćwiczeń (SSP) autorstwa Zbigniewa Szota. Jest to forma terapii ukierunkowana na stymulowanie aktywności ruchowej dziecka. Wykonywane ćwiczenia mają na celu pobudzanie pracy mózgu, a przy tym poprawianie sprawności oraz koordynację funkcji nerwowo-mięśniowych (Puszczałowska-Lizis, Biała, 2016). W terapii wyróżnia się ćwiczenia: kształtujące, lokomocyjne, równoważne w zwisach, zwinnościowe, skoczne, rzutne, stosowane oraz gry i zabawy (Szot, 1997). Dobór ćwiczeń jest zależny od indywidualnych potrzeb dziecka. Do najważniejszych cech terapii prowadzonej według Metody Stymulowanych Seryjnych Powtórzeń Ćwiczeń należy fakt, iż ćwiczenia mogą być wykonywane w każdych warunkach są dobierane odpowiednio do możliwości osoby ćwiczącej. Ponadto ćwiczenia powinny być wykonywane seriami lecz program może być modyfikowany w zależności od potrzeb dziecka z zaburzeniami ze spektrum autyzmu (Kucharski 2005). Co najważniejsze ćwiczenia dobrane według tej metody pozwalają na stymulowanie czucia prioprioceptywnego oraz doskonalenia koncentracji uwagi, a także czynności, które mogą być wykorzystywane w codziennym funkcjonowaniu, co jest bardzo ważne w przypadku osób z autyzmem.

Jako ostatnia wśród metod wykorzystywanych w terapii dzieci z autyzmem zostanie wskazana Metoda Wymuszonego Kontaktu, tzw. holding therapy. Została opracowana przez Marthę Welch z Mothering Center w Greenwich w Stanach Zjednoczonych Ameryki. Metoda oparta jest na procesie tworzenia się więzi uczuciowej pomiędzy dzieckiem a jego matką, gdzie kontakt cielesny jest podstawą do budowania poprawnych relacji społecznych i emocjonalnych (Bobkowicz-Lewartowska, 2007, za: Puszczałowska-Lizis, Biała 2017). Do prowadzenia terapii tą metodą wymagany jest spokój. Wyróżnia się 3 fazy przebiegu terapeutycznego: fazę konfrontacji, fazę odrzucenia oraz fazę rozwiązania. Matka osiąga przewagę nad dzieckiem przez co odbudowuje relację z nim. Terapeuta zaś wyjaśnia i nadzoruje proces terapeutyczny (Bobkowicz-Lewartowska 2007, za: Puszczałowska-Lizis, Biała 2017). Zgodnie z założeniami ćwiczenia powinny być systematycznie powtarzane w czasie których zapewniony jest maksymalny komfort. 
Zaprezentowane metody stanowią jedynie fragment tego co można odnaleźć w literaturze oraz ofercie szkoleń poświęconych wspomaganiu funkcjonowania osób z autyzmem. Najważniejsze jednak jest, by w momencie doboru sposobów oraz metod oddziaływania mieć na uwadze potrzeby, możliwości oraz bariery dziecka ze specjalnymi potrzebami. Natomiast w czasie terapii konieczna jest wytężona oraz systematyczna praca.

\section{Podsumowanie}

Podsumowując powyższy przegląd metod pracy z uczniem z autyzmem należy wspomnieć, jak ważny jest dobór odpowiednich metod do potrzeb oraz trudności ucznia. Istotna jest także współpraca pomiędzy specjalistami oraz rodzicami. Niezależnie od preferowanej metody najważniejsza jest systematyczność oraz jednotorowe oddziaływanie. Jest to niezwykle ważne szczególnie w przypadku dzieci młodszych, w tym także w wieku wczesnoszkolnym. W okresie tym dzieci nabywają umiejętności, które będą wykorzystywały w dorosłym życiu. Zatem tylko skorelowane działania oraz współpraca dla dobra dziecka możne zaowocować sukcesami w przyszłym funkcjonowaniu poznawczym, społecznym i emocjonalnym oraz komunikacji.

\section{Bibliografia}

Biernat, R. (2014). Metody i techniki terapeutycznego oddziatywania i wspomagania dzieci z zaburzeniami i deficytami rozwojowymi w wieku przedszkolnym i wczesnoszkolnym, Płock: Państwowa Wyższa Szkoła Zawodowa w Płocku.

Chmiel, K., Kubińska, Z., Derewiecki, T. (2014). Terapie z udziałem zwierząt w rehabilitacji różnych form niepełnosprawności, Probl Hig Epidemiol 2014, 95(3): 591-595.

Cieszyńska, J. (2011). Wczesna diagnoza i terapia zaburzeń autystycznych Metoda krakowska, Kraków: Wydawnictwo Omega Stage Systems - Jędrzej Cieszyński.

Gerc, K. (2012). Autyzm i zespół Aspergera jako zaburzenie neurorozwojowe próba charakterystyki wybranych stanowisk naukowych w świetle przeglądu współczesnych badań, Sztuka Leczenia 2012, nr 3-4, s. 33-46

Grandin, T. (2018). Mózg autystyczny. Podróż w gtąb niezwyktych umystów, Wyd. III, Kraków: Wydawnictwo Copernicus Center Press.

Kaufman, R.K. (2016). Autyzm przetom w podejściu. Program Son-Rise, który pomógt rodzicom na catym świecie, Białystok: Wydawnictwo Vivante. 
Kołakowski, A., Pisula, A. (2016). Sposób na trudne dziecko. Przyjazna terapia behawioralna, Sopot: Gdańskie Wydawnictwo Psychologiczne.

Komorowska-Szczepańska, W. (2015). Autyzm. Opis przypadku, Forum Medycyny Rodzinnej 2015, tom 9, nr 3, 235-236.

Kucharski, K. (2005). Metoda Stymulowanych Seryjnych Powtórzeń Ćwiczeń (SSP)Zbigniewa Szota. W: J. Błeszyński (red.), Terapie wspomagające rozwój osób z autyzmem, Kraków: Oficyna wydawnicza Impuls.

Odowska-Szlachcic, B. (2013). Terapia integracji sensorycznej. Strategie terapeutyczne i ćwiczenia stymulujące uktady: stuchowy, wzrokowy, węchu i smaku oraz terapia świattem i kolorami, Gdańsk: Wydawnictwo HARMONIA.

Pisula, E. (2010). Autyzm: przyczyny, symptomy, terapia, Gdańsk: Wydawnictwo Harmonia.

Puszczałkowska-Lizis, E., Biała, E.A. (2017). Terapia osób o specjalnych potrzebach, Warszawa: Fraszka Edukacyjna.

Skawina, S. (2016). Autyzm i zespót Aspergera. Objawy, przyczyny, diagnoza i wspótczesne metody terapeutyczne. Nová sociálna edukácia človeka V, Medzinárodná interdisciplinárna vedecká konferencia, Prešov: 7.11.2016.

Szeler, K. (2007). Wybrane metody terapii osób dotkniętych autyzmem w świetle literatury, Paedogika Christiana, 2(20)/ 2007.

Szot, Z. (1997). Aktywność ruchowa w terapii dzieci autystycznych, Gdańsk: Wydawnictwa Uczelniane AWF.

Wolski, A. (2012). Praktyczny wymiar realizacji zajęć technicznych $w$ gimnazjum z uczniami z autyzmem i dodatkowymi zaburzeniami rozwojowymi. W: D. Wolska, A. Mikrut (red.), Annales Universitatis Paedagogicae Cracoviensis, Studia Paedagogica II.

\section{Netografia:}

http://www.synapsis.org.pl/zycie-z-autyzmem/poradnik-dla-nauczycieli/ funkcjonowanie-osob-z-autyzmem-na-co-zwroci-szczegoln-uwag (dostęp: 10.04.2019)

http://niegrzecznedzieci.org.pl/asperger/swiat-nauki/terapia/metoda-opcji/ (dostęp: 12.04.2019)

https://polskiautyzm.pl/podejscie-teacch-w-terapii-autyzmu/ (dostęp: 13.04.2019) 


\title{
Review of Selected Methods of Work with Children with Autism in the Early School Age
}

\begin{abstract}
The article describes the ways of working with children with autism in an early school age.

The characteristic features of this disorder, which is autism, have been described. Methods included in directives and non-directive forms of work were presented. The author briefly described the most important features of each therapy. In conclusion, she concluded that in the selection of methods of working with children with autism it is necessary to take into account first of all the needs of the child, its capabilities and barriers. In addition, the importance of systematic and intensive therapeutic work as well as the cooperation of specialists and parents have been raised.
\end{abstract}

Key words: autism, methods of work, early school education 